\title{
Venomics and antivenomics of the poorly studied Brazil's lancehead, Bothrops brazili (Hoge, 1954), from the Brazilian State of Pará
}

\author{
Libia Sanz ${ }^{1}$, Alicia Pérez ${ }^{1}$, Sarai Quesada-Bernat ${ }^{1}$, Rafaela Diniz-Sousa ${ }^{2,3,4}$, Leonardo A. Calderón ${ }^{2,3,5,6}$, \\ Andreimar M. Soares ${ }^{2,3,4,5,7}$, Juan J. Calvete,* (D), Cleópatra A.S. Caldeira ${ }^{2,3,5}$ (D) \\ ${ }^{1}$ Evolutionary and Translational Venomics Laboratory, Spanish National Research Council (CSIC), Valencia, Spain. \\ ${ }^{2}$ Center for the Study of Biomolecules Applied to Health (CEBio), Oswaldo Cruz Foundation Rondônia, Porto Velho, RO, Brazil. \\ ${ }^{3}$ Graduate Program in Experimental Biology (PGBIOEXP), Federal University of Rondônia (UNIR), Porto Velho, RO, Brazil. \\ ${ }^{4}$ São Lucas University Center (UniSL), Porto Velho, RO, Brazil. \\ ${ }^{5}$ Graduate Program in Biodiversity and Biotechnology, BIONORTE Network, Porto Velho, RO, Brazil. \\ ${ }^{6}$ Aparício Carvalho University Center (FIMCA), Porto Velho, RO, Brazil. \\ ${ }^{7}$ National Institute of Science and Technology in Epidemiology of the Western Amazônia, (INCT-EpiAmO), Porto Velho, RO, Brazil.
}

\author{
Keywords: \\ Snake venom \\ Bothrops brazili \\ Venomics \\ Third-generation \\ antivenomics \\ Brazilian antibothropic \\ polyvalent antivenom
}

\footnotetext{
* Correspondence: jcalvete@ibv.csic.es https://doi.org/10.1590/1678-9199-JVATITD-2019-0103 Received: 19 December 2019; Accepted: 28 February 2020; Published online: 17 April 2020

\begin{abstract}
Background: The Brazil's lancehead, Bothrops brazili, is a poorly studied pit viper distributed in lowlands of the equatorial rainforests of southern Colombia, northeastern Peru, eastern Ecuador, southern and southeastern Venezuela, Guyana, Suriname, French Guiana, Brazil, and northern Bolivia. Few studies have been reported on toxins isolated from venom of Ecuadorian and Brazilian B. brazili. The aim of the present study was to elucidate the qualitative and quantitative protein composition of $B$. brazili venom from Pará (Brazil), and to carry out a comparative antivenomics assessment of the immunoreactivity of the Brazilian antibothropic pentavalent antivenom [soro antibotrópico (SAB) in Portuguese] against the venoms of $B$. brazili and reference species, B. jararaca.

Methods: We have applied a quantitative snake venomics approach, including reversephase and two-dimensional electrophoretic decomplexation of the venom toxin arsenal, LC-ESI-MS mass profiling and peptide-centric MS/MS proteomic analysis, to unveil the overall protein composition of B. brazili venom from Pará (Brazil). Using third-generation antivenomics, the specific and paraspecific immunoreactivity of the Brazilian SAB against homologous (B. jararaca) and heterologous (B. brazili) venoms was investigated. Results: The venom proteome of the Brazil's lancehead (Pará) is predominantly composed of two major and three minor acidic (19\%) and two major and five minor basic (14\%) phospholipase $\mathrm{A}_{2}$ molecules; 7-11 snake venom metalloproteinases of classes PI (21\%) and PIII (6\%); 10-12 serine proteinases (14\%), and 1-2 L-amino acid oxidases (6\%).
\end{abstract}


Other toxins, including two cysteine-rich secretory proteins, one C-type lectin-like molecule, one nerve growth factor, one 5'-nucleotidase, one phosphodiesterase, one phospholipase $\mathrm{B}$, and one glutaminyl cyclase molecule, represent together less than $2.7 \%$ of the venom proteome. Third generation antivenomics profile of the Brazilian pentabothropic antivenom showed paraspecific immunoreactivity against all the toxin classes of B. brazili venom, with maximal binding capacity of $132.2 \mathrm{mg}$ venom/g antivenom. This figure indicates that $19 \%$ of antivenom's $F(a b ')_{2}$ antibodies bind $B$. brazili venom toxins.

Conclusion: The proteomics outcome contribute to a deeper insight into the spectrum of toxins present in the venom of the Brazil's lancehead, and rationalize the pathophysiology underlying this snake bite envenomings. The comparative qualitative and quantitative immunorecognition profile of the Brazilian pentabothropic antivenom toward the venom toxins of B. brazili and B. jararaca (the reference venom for assessing the bothropic antivenom's potency in Brazil), provides clues about the proper use of the Brazilian antibothropic polyvalent antivenom in the treatment of bites by the Brazil's lancehead.

\section{Background}

The genus Bothrops includes at least 50 species of pit vipers (Viperidae: Crotalinae) that are widely distributed throughout the Americas, from Mexico to southern Argentina, in different ecoregions, from tropical and subtropical forests to arid and semiarid regions, and from sea level to altitudes of more than 3000 $\mathrm{m}[1,2]$. Bothrops species exhibit extreme diverse morphological and ecological traits, including terrestrial, arboreal and semiarboreal species, many of which show generalist, while others show specialized dietary habits (e.g. rodents or birds), and ontogenetic shifts in diet [3]. Although still subject to taxonomic instability [4], all the clades within genus Bothrops include species that represent the main medically important venomous snakes in their range [5-7]. The clinical presentations of patients suffering from envenomations by viperid snakes show both local tissue damage and systemic manifestations, such as hemorrhage, coagulopathies and hemodynamic instability $[6,8]$.

In Ecuador, 1200-1400 cases of snakebites are yearly reported in 19 of the 21 provinces. East of the Andes, the principal venomous species are the common lancehead (B. atrox) and two-striped forest pitviper (B. bilineatus smaragdinus) [9]. The main clinical effects of envenomings by $B$. atrox are life threatening bleeding and blood coagulation disorders, shock, and renal failure. Other species such as B. brazili and L. muta, although potentially as dangerous as $B$. atrox, rarely bite people and envenoming by B. b. smaragdinus is usually less severe [9]. The vast majority of snakebites in Peru are inflicted by species of the genus Bothrops [10]. Bothrops brazili, distributed in the tropical rainforests in the eastern part of the country, is one of the main species responsible for snakebite accidents in Peru, and its venom composes the antigenic pool used to produce bothropic antivenom in this country. Peruvian bothropic antivenom (P-BAV) is an IgG solution obtained from horses immunized with a pool of venoms, consisted of $50 \%$ of B. atrox venom and $12.5 \%$ of pooled venom from other species (B. pictus, B. barnetti, B. brazili and Bothrocophias hyoprora) [11]. In French Guiana, B. atrox, B. brazili, B. bilineatus, L. muta and Micrurus sp. are responsible for most cases of snakebite envenomation [8]. Different from other Brazilian regions, B. atrox, B. brazili and $B$. taeniata are responsible for almost $90 \%$ of human accidents in the Rio Negro Amazonian region $[12,13]$.

Named in honor of the Brazilian physician and herpetologist Vital Brazil Mineiro da Campanha [14], founder and former director of the Butantan Institute in São Paulo, the Brazil's lancehead, Bothrops brazili (Hoge, 1954) [15], is a stoutly built terrestrial venomous pit viper endemic to South America. Phylogenetic studies recover B. brazili and B. jararacuss $u$ within the "jararacussu" group, a sister branch of the monophyletic "asper-atrox" species clade [2, 16]. Despite being a wide-ranging species, which inhabits in lowlands of the equatorial rainforests of southern Colombia, northeastern Peru, eastern Ecuador, southern and southeastern Venezuela, Guyana, Suriname, French Guiana, Brazil (Acre, Amazonas, Mato Grosso, Maranhão, Pará and Rondônia), and northern Bolivia [1, 17, 18], no subspecies are currently recognized for the Brazil's lancehead. Terrestrial and mainly a nocturnal snake, adults of B. brazili are usually $70-90 \mathrm{~cm}$ in total length (including tail), but may exceed $140 \mathrm{~cm}$. Among adult specimens, females are much larger than males [1]. Data from specimens from the Brazilian states Maranhão, Pará and Rondônia [3], and from the upper Amazon basin, Iquitos Region, Peru [19], indicated that Brazil's lanceheads exhibit ontogenetic shift in prey type diet from invertebrate ectotherms to vertebrate ecto- and endotherms. Centipedes are common prey items of juveniles whereas adults are generalists feeding mainly on rodents, anurans, and lizards.

Peruvian B. brazili produces large amounts of venom (3-4 mL) [20] with potent median lethal dose $\left(\mathrm{LD}_{50}\right)$ in mice of $15.27 \mu \mathrm{g} / 18-20 \mathrm{~g}$ mouse compared to $49.90 \mu \mathrm{g} / \mathrm{mouse}(B$. atrox), $45.22 \mu \mathrm{g} / \mathrm{mouse}$ (B. bilineatus), and $58.91 \mu \mathrm{g} / \mathrm{mouse}$ 
(B. pictus) [11]. In the murine model, Peruvian B. brazili exhibited minimum hemorrhagic dose (MHD) of $7.40 \mu \mathrm{g} /$ mouse), minimum dermonecrotic dose (MND) of $152.15 \mu \mathrm{g} /$ mouse, minimum coagulant dose against plasma (MCD-P) and fibrinogen (MCD-F) of 19.20 and $1020.0 \mu \mathrm{g} / \mathrm{mL}$, respectively, and minimum defibrinogenating dose (MDD) of $7.0 \mu \mathrm{g} / \mathrm{mouse}$ [11]. Although described as a new Bothrops from Brazil 65 years ago [15], very few studies have been reported on the toxin arsenal of the Brazil's lancehead venom, and these were mainly focused on the pharmacological effects and possible biotechnological applications of isolated toxins [21-31], including acidic and basic phospholipase $\mathrm{A}_{2}\left(\mathrm{PLA}_{2}\right.$ ) molecules (myotoxic Braziliase I and II, MTX I and II, brazilitoxins II and III) [23-26]; a PI-snake venom metaloproteinase (SVMP), with in vitro antiplasmodial properties [27]; coagulant thrombin-like and pro-angiogenic snake venom serine proteinase (SVSP) [28, 29]; and a hyaluronidase [30].

Recently, Gren and et al. [31] reported the presence of 5'-nucleotidase (5'-NT), C-type lectin-like (CTL), L-amino acid oxidase (LAO), phosphodiesterase (PDE), phospholipases $\mathrm{A}_{2}\left(\mathrm{PLA}_{2}\right)$ and $\mathrm{B}$ (PLB), and SVMP molecules in the high molecular size-exclusion chromatographic fraction of a number of bothropic venoms, including B. brazili [31]. However, venoms comprise mixtures of toxins, which act jointly dysregulating receptors involved in maintaining vital systems and wreak havoc on internal organs of the prey. Understanding such integrated complex phenotype demands a holistic view of the system. With this in mind, we have applied a snake venomics approach to elucidate the qualitative and quantitative protein composition of B. brazili venom from Pará (Brazil), and a comparative antivenomics assessment of the immunoreactivity of the Brazilian antibothropic pentavalent antivenom against the venoms of B. brazili and B. jararaca, the latter used as a reference venom.

\section{Materials and Methods Venom and antivenom}

Pooled venom from B. brazili (State of Pará, Brazil) was acquired from Serpentário Proteínas Bioativas Ltda, Batatais, SP, and kept refrigerated $\left(8^{\circ} \mathrm{C}\right)$ in the Bank of Amazon Venoms at the Center of Biomolecules Studies Applied to Health, CEBioUNIR-FIOCRUZ-RO (register CGEN A4D12CB and IBAMA/ SISBIO 64385-1). The antibothropic pentavalent antivenom (soro antibotrópico pentavalente, SAB; batch 1305077; production date: 05/2013) from Butantan Institute (São Paulo, Brazil) was raised in horses by conventional immunization schedules against a pool of venoms from $B$. jararaca (50\%), B. jararacussu (12.5\%), B. moojeni (12.5\%), B. alternatus (12.5\%) and B. neuwiedi (12.5\%). The final formulation consists of purified $\mathrm{F}(\mathrm{ab})_{2}$ fragments generated by digestion with pepsin of ammonium sulfateprecipitated IgG molecules $[32,33]$. A vial of SAB $[10 \mathrm{~mL}$, $29.2 \mathrm{mg} \mathrm{F}\left(\mathrm{ab}^{\prime}\right)_{2} / \mathrm{mL}$ ] neutralizes $50 \mathrm{mg}$ of $B$. jararaca venom (the reference venom for assessing the bothropic antivenom potency in Brazil).

\section{Isolation and initial characterization of B. brazili (Pará) venom proteins}

Crude lyophilized venom was dissolved in $0.05 \%$ trifluoroacetic acid (TFA) and 5\% acetonitrile (ACN) to a final concentration of $15 \mathrm{mg} / \mathrm{mL}$. Insoluble material was removed by centrifugation in an Eppendorf centrifuge at 13,000xg for $10 \mathrm{~min}$ at room temperature, and the proteins contained in $40 \mu \mathrm{L}(600 \mu \mathrm{g})$ were separated by RP-HPLC using a Agilent LC 1100 High Pressure Gradient System equipped with a Teknokroma Europa C18 (25 $\mathrm{cm} \times 5 \mathrm{~mm}, 5 \mu \mathrm{m}$ particle size, $300 \AA$ A pore size) column and a DAD detector. The column was developed at a flow rate of 1.0 $\mathrm{mL} / \mathrm{min}$ with a linear gradient of $0.1 \%$ TFA in MilliQ ${ }^{\circledR}$ water (solution $\mathrm{A}$ ) and $0.1 \%$ TFA in acetonitrile (solution $\mathrm{B}$ ), isocratic (5\% B) for $5 \mathrm{~min}$, followed by $5-25 \%$ B for $10 \mathrm{~min}, 25-45 \%$ B for $60 \mathrm{~min}$, and $45-70 \% \mathrm{~B}$ for $10 \mathrm{~min}$. Protein detection was carried out at $215 \mathrm{~nm}$ with a reference wavelength of $400 \mathrm{~nm}$. Fractions were collected manually across the entire elution range, dried in a vacuum centrifuge (Savant ${ }^{\mathrm{Tm}}$, ThermoFisher Scientific), and redissolved in MilliQ ${ }^{\circ}$ water. Molecular masses of the purified proteins were estimated by non-reduced and reduced Tris-Tricine SDS-PAGE (on $15 \%$ polyacrylamide gels) [34], or determined by electrospray ionization (ESI) mass spectrometry (MS).

For SDS-PAGE analysis sample aliquots were mixed with $1 / 4$ volume of $4 \mathrm{x}$ sample buffer $(0.25 \mathrm{M}$ Tris- $\mathrm{HCl} \mathrm{pH} 6.8,8 \%$ SDS, $30 \%$ glycerol, $0.02 \%$ bromophenol blue, with or without $10 \%$ 2-mercaptoethanol) and heated at $85^{\circ} \mathrm{C}$ for $15 \mathrm{~min}$, run under reducing conditions, and the gels were stained with Coomassie Brilliant Blue G-250. For ESI-MS mass profiling, the proteins eluted in the different RP-HPLC fractions were separated by nano-Acquity UltraPerformance LC ${ }^{\circledast}$ (UPLC ${ }^{\circledast}$ ) using BEH130 C18 $(100 \mu \mathrm{m}$ x $100 \mathrm{~mm}, 1.7 \mu \mathrm{m}$ particle size $)$ column in-line with a Waters SYNAPT G2 High Definition Mass Spectrometry System. The flow rate was set to $0.6 \mu \mathrm{L} / \mathrm{min}$ and the column was developed with a linear gradient of $0.1 \%$ formic acid in water (solution $\mathrm{A}$ ) and $0.1 \%$ formic acid in ACN (solution $\mathrm{B}$ ), isocratically $1 \% \mathrm{~B}$ for $1 \mathrm{~min}$, followed by $1-12 \% \mathrm{~B}$ for $1 \mathrm{~min}$, $12-40 \%$ B for $15 \mathrm{~min}, 40-85 \%$ B for $2 \mathrm{~min}$. Monoisotopic and isotope-averaged molecular masses were calculated by manually deconvolution of the isotope-resolved multiply-charged MS1 mass spectra.

\section{Two-dimensional (IEF/SDS-PAGE) gel electrophoresis}

Two-dimensional gel electrophoresis (2-DE) was performed essentially according to the manufacturer's (GE Healthcare Amersham Biosciences) instructions unless otherwise indicated. For the first dimension, isoelectric focusing (IEF), $\sim 150 \mu \mathrm{g}$ of venom were dissolved in $7 \mathrm{M}$ urea, $2 \mathrm{M}$ thiourea, $4 \%$ CHAPS, and $0.5 \%$ IPG buffer $\mathrm{pH}$ 3-10 and applied onto 7-cm pH 3-10 nonlinear, immobilized $\mathrm{pH}$ gradient (IPG) ReadyStrip ${ }^{\mathrm{Tm}}$ strips. IEF was carried out with an Ettan-IPGphor isoelectric focusing unit at $20^{\circ} \mathrm{C}$ applying the following conditions: $300 \mathrm{~V}(0.5 \mathrm{~h})$, ramping to $1000 \mathrm{~V}(0.5 \mathrm{~h})$, ramping to $5000(1.3 \mathrm{~h})$ and $5000 \mathrm{~V}$ 
(0.5 h). After IEF, the IPG strips were kept at $-70^{\circ} \mathrm{C}$ until use. For the second dimension, SDS-polyacrylamide gel electrophoresis (SDS-PAGE), the IPGs were equilibrated for $15 \mathrm{~min}$ with gentle shaking and at room temperature in equilibration buffer $[6 \mathrm{M}$ urea, 2\% (w/v) SDS, 30\% (v/v) glycerol, $75 \mathrm{mM}$ Tris-HCl, $\mathrm{pH}$ 8.8], with or without $40 \mathrm{mM}$ DTT. IPG strips were then placed on top of SDS-15\% polyacrylamide gels and run in a Protean II (Bio-Rad) electrophoresis unit at room temperature. Protein spots were visualized by Coomassie Brilliant Blue G250 staining.

\section{Characterization and relative quantification of RP-HPLC fractions and 2-DE protein spots of the Brazil's lancehead venom peptidome and proteome}

Protein bands of interest were excised from Coomassie Brilliant Blue-stained SDS-PAGE and 2-DE gels and subject to in-gel disulfide bond reduction $(10 \mathrm{mM}$ dithiothreitol, $30 \mathrm{~min}$ at 65 ${ }^{\circ} \mathrm{C}$ ) and cysteine alkylation (50 $\mathrm{mM}$ iodoacetamide, $2 \mathrm{~h}$ in the dark at room temperature), followed by overnight digestion with sequencing-grade trypsin $(66 \mathrm{ng} / \mu \mathrm{L}$ in $25 \mathrm{mM}$ ammonium bicarbonate, $10 \% \mathrm{ACN} ; 0.25 \mu \mathrm{g} / \mathrm{sample})$, using a Genomics Solution ProGest ${ }^{\mathrm{m}}$ Protein Digestion Workstation. Tryptic digests were dried in a vacuum centrifuge (SPD SpeedVac ${ }^{\oplus}$, ThermoSavant), redissolved in $14 \mu \mathrm{L}$ of $5 \%$ ACN containing $0.1 \%$ formic acid, and $7 \mu \mathrm{L}$ submitted to LC-MS/MS. Tryptic peptides were separated by nano-Acquity UltraPerformance LC $^{\oplus}\left(\right.$ UPLC $\left.^{\circledR}\right)$ as above.

Doubly and triply charged ions were selected for CID-MS/ MS. Fragmentation spectra were interpreted i) manually (de novo sequencing), ii) using the on-line form of the MASCOT Server (version 2.6) at http://www.matrixscience.com against the last update (Release 234 of October 15th, 2019) of NCBI nonredundant database, and iii) processed in Waters Corporation's ProteinLynx Global SERVER 2013 version 2.5.2. (with Expression version 2.0). The following search parameters were used: Taxonomy: bony vertebrates; Enzyme: trypsin (two missed cleavage allowed); MS/MS mass tolerance was set to $\pm 0.6 \mathrm{Da}$; carbamidomethyl cysteine and oxidation of methionine were selected as fixed and variable modifications, respectively. All matched MS/MS data were manually checked. Peptide sequences assigned by de novo MS/MS were matched to homologous proteins available in the NCBI non-redundant protein sequences database using the online BLASTP program [35] at https://blast. ncbi.nlm.nih.gov/Blast.cgi.

The relative abundances of the chromatographic peaks obtained by reverse-phase HPLC fractionation of the whole venom were calculated as "\% of total peptide bond concentration in the peak" by dividing the peak area by the total area of the chromatogram [36-38]. For chromatographic peaks containing single components (as judged by SDS-PAGE and/or MS), this figure is a good estimate of the $\%$ by weight $(\mathrm{g} / 100 \mathrm{~g})$ of the pure venom component [39]. When more than one venom protein was present in a reverse-phase fraction, their proportions (\% of total protein band area) were estimated by densitometry of Coomassie-stained SDS-polyacrylamide gels using MetaMorph ${ }^{\circ}$
Image Analysis Software (Molecular Devices). Conversely, the relative abundances of different proteins contained in the same SDS-PAGE band were estimated based on the relative ion intensities of the three most abundant peptide ions associated with each protein by MS/MS analysis. The relative abundances of the protein families present in the venom were calculated as the ratio of the sum of the percentages of the individual proteins from the same toxin family to the total area of venom protein peaks in the reverse-phase chromatogram.

\section{Third-generation antivenomics}

Third-generation antivenomics [40,41] was applied to compare the immunoreactivity of the Brazilian pentabothropic antivenom (SAB) towards the venoms of B. brazili and B. jararaca from the southeastern clade population within the Brazilian Atlantic forest [42] (used as reference venom). To this end, one vial of antivenom was dialyzed against MilliQ ${ }^{\bullet}$ water, lyophilized, and $150 \mathrm{mg}$ of total lyophilizate weight were reconstituted in $6 \mathrm{~mL}$ of $0.2 \mathrm{M} \mathrm{NaHCO}_{3}, 0.5 \mathrm{M} \mathrm{NaCl}, \mathrm{pH} 8.3$ (coupling buffer). The concentrations of this antivenom stock solution $[21.62 \mathrm{mg}$ $\mathrm{F}\left(\mathrm{ab}^{\prime}\right)_{2} / \mathrm{mL}$ ] was determined spectrophotometrically using an extinction coefficient for a $1 \mathrm{mg} / \mathrm{mL}$ concentration $\left(\varepsilon^{0.1 \%}\right)$ at $280 \mathrm{~nm}$ of $1.36\left(\mathrm{mg} / \mathrm{mL}^{-1} \mathrm{~cm}^{-1}[43]\right.$.

Antivenom affinity columns were prepared in batch. To this end, $3 \mathrm{~mL}$ of CNBr-activated Sepharose ${ }^{\mathrm{mt}} 4 \mathrm{~B}$ matrix (Ge Healthcare, Buckinghamshire, UK) packed in a ABT column (Agarose Bead Technologies, Torrejón de Ardoz, Madrid) and washed with $15 x$ matrix volumes of cold $1 \mathrm{mM} \mathrm{HCl}$, followed by two matrix volumes of coupling buffer to adjust the $\mathrm{pH}$ of the column to 8.0-9.0. CNBr-activated instead of $\mathrm{N}$-hydroxysuccinimide (NHS)-activated matrix was employed because NHS released during the coupling procedure absorbs strongly at $280 \mathrm{~nm}$, thus interfering with the measurement of the concentration of antibodies remaining in the supernatant of the coupling solution. One hundred thirty $\mathrm{mg}$ of antivenom dissolved in $6 \mathrm{~mL}$ of coupling buffer were incubated with $3 \mathrm{~mL}$ $\mathrm{CNBr}$-activated matrix for $4 \mathrm{~h}$ at room temperature. Antivenom coupling yield, estimated measuring $\mathrm{A}_{280 \mathrm{~nm}}$ before and after incubation with the matrix, was $95.7 \mathrm{mg}$ (i.e., $31.9 \mathrm{mg} \mathrm{F}\left(\mathrm{ab}^{\prime}\right)_{2} /$ $\mathrm{mL} \mathrm{CNBr}$-activated Sepharose ${ }^{\mathrm{Tw}} 4 \mathrm{~B}$ matrix).

After the coupling, remaining active matrix groups were blocked with $3 \mathrm{~mL}$ of $0.1 \mathrm{M}$ Tris- $\mathrm{HCl}, \mathrm{pH} 8.5$ at room temperature for $4 \mathrm{~h}$. Affinity columns, each containing $282 \mu \mathrm{L}$ of affinity matrix containing $9 \mathrm{mg}$ of immobilized $\mathrm{SAB} F\left(\mathrm{ab}{ }^{\prime}\right)_{2}$ molecules, were alternately washed with three matrix volumes of $0.1 \mathrm{M}$ acetate containing $0.5 \mathrm{M} \mathrm{NaCl}, \mathrm{pH} 4.0-5.0$, and three matrix volumes of $0.1 \mathrm{M}$ Tris- $\mathrm{HCl}, \mathrm{pH}$ 8.5. This procedure was repeated 6 times. The columns were then equilibrated with three volumes of working buffer (PBS, $20 \mathrm{mM}$ phosphate buffer, $135 \mathrm{mM} \mathrm{NaCl}$, $\mathrm{pH}$ 7.4) and incubated with increasing amounts (100-3600 $\mu \mathrm{g}$ of total venom proteins) of $B$. brazili or B. jararaca dissolved in $1 / 2$ matrix volume of PBS, and the mixtures incubated for $1 \mathrm{~h}$ at $25^{\circ} \mathrm{C}$ in an orbital shaker. 
As specificity controls, $300 \mu \mathrm{L}$ of $\mathrm{CNBr}$-activated Sepharose $\mathrm{T}^{\mathrm{TM}}$ $4 \mathrm{~B}$ matrix, without (mock) or with $9 \mathrm{mg}$ of immobilized control (naïve) horse IgGs, were incubated with venom and developed in parallel to the immunoaffinity columns. The non-retained eluates of columns incubated with 100-300, 600, 900, 1200, 2400, $3600 \mu \mathrm{g}$ of venom were recovered, respectively, with $3 \mathrm{x}, 5 \mathrm{x}, 7 \mathrm{x}$, $9 \mathrm{x}, 17 \mathrm{x}$ and $25 \mathrm{x}$ matrix volume of PBS, and the immunocaptured proteins were eluted, respectively, with $3 x(100-300 \mu \mathrm{g})$ and $6 \mathrm{x}(600-3600 \mu \mathrm{g})$ matrix volume of $0.1 \mathrm{M}$ glycine- $\mathrm{HCl}, \mathrm{pH} 2.7$ buffer, and brought to neutral $\mathrm{pH}$ with $1 \mathrm{M}$ Tris- $\mathrm{HCl}, \mathrm{pH} 9.0$. The entire fractions eluted in $100-300 \mu \mathrm{g}, 1 / 2$ of the fractions recovered in $600 \mu \mathrm{g}, 1 / 3$ of the non-retained fractions and $1 / 2$ of the retained fractions recovered in $900 \mu \mathrm{g}, 1 / 4$ of the nonretained fractions and $1 / 2$ of the retained fractions recovered in $1200 \mu \mathrm{g}, 1 / 8$ of the non-retained fractions and $1 / 4$ of the retained fractions recovered in $2400 \mu \mathrm{g}$ and $1 / 12$ of the non-retained fractions and $1 / 4$ of the retained fractions recovered in $3600 \mu \mathrm{g}$, were concentrated in a Savant SpeedVac ${ }^{\mathrm{TM}}$ vacuum centrifuge (ThermoFisher Scientific, Waltham, MA USA) to $45 \mu \mathrm{L}, 40 \mu \mathrm{L}$ of which were then fractionated by reverse-phase HPLC using an Agilent LC 1100 High Pressure Gradient System (Santa Clara, CA, USA) equipped with a Discovery ${ }^{\circledR}$ BIO Wide Pore C18 (15 $\mathrm{cm} \times 2.1 \mathrm{~mm}, 3 \mu \mathrm{m}$ particle size, $300 \AA$ pore size) column and a DAD detector as above.

Eluate was monitored at $215 \mathrm{~nm}$ with a reference wavelength of $400 \mathrm{~nm}$. The fraction of non-immunocaptured molecules was estimated as the relative ratio of the chromatographic areas of the toxin recovered in the non-retained (NR) and retained (R) affinity chromatography fractions using the equation:

$$
\% \mathrm{NRi}=100-\left[\frac{\mathrm{Ri}}{\mathrm{Ri}+\mathrm{NRi}} \times 100\right]
$$

where Ri corresponds to the area of the same protein " $i$ " in the chromatogram of the fraction retained and eluted from the affinity column. However, for some toxins that were poorly recovered in the column-retained fraction owing to their high binding affinity to the immobilized antivenom likely preventing their elution from the column [44], the percentage of nonimmunocaptured toxin “i” (\% NRtoxin“i”) was calculated as the ratio between the chromatographic areas of the same peak recovered in the non-retained fraction (NRtoxin “ $i$ ”) and in a reference venom (Vtoxin“i”) containing the same amount of total protein that the parent venom sample and run under identical chromatographic conditions, using the equation:

$$
\text { \%NRtoxin“i” }=\frac{\text { NRtoxin“i”” }}{\text { Vtoxin“i”" }} \times 100
$$

The percentage of antivenom anti-toxin $\mathrm{F}\left(\mathrm{ab}^{\prime}\right)_{2}$ molecules was calculated by dividing [(1/2 maximal amount (in $\mu$ moles) of total venom proteins bound per antivenom vial) $\mathrm{x}$ molecular mass (in $\mathrm{kDa}$ ) of antibody (F(ab'), $110 \mathrm{kDa})$ molecule] by the [total amount of antibody $\left(\mathrm{F}\left(\mathrm{ab}^{\prime}\right)_{2}\right)$ (in $\mathrm{mg}$ ) per antivenom vial]
$[41,45,46]$. Binding saturation was computed by extrapolation from data modelled in Excel to degree 2 polynomial functions.

\section{Results and Discussion}

\section{ESI-MS mass profiling across the reverse-phase HPLC separation of the Brazil's lancehead venom proteome}

The venom proteome of $600 \mu \mathrm{g}$ of crude venom of $\mathrm{B}$. brazili (Pará) was decomplexed and quantified by reverse-phase HPLC and downstream SDS-PAGE analysis of the chromatographic peaks (Fig. 1, Additional file 1). Twenty major and 25 minor chromatographic peaks were recovered, and the electrophoretic analysis of these fractions showed that most comprised a major component and a variable number of minor bands (Fig. 1, inset). Since only proteins with identical chemical formulae are isobaric, mass profiling represents a convenient approach for identifying a venom by means of its mass fingerprint and differentiating it not only from other species' venoms but also from geographical variants within the same species $[47,48]$. To highlight molecular markers of $B$. brazili (Pará) venom investigated in this work, RP-HPLC fractions 2-46 were submitted to molecular mass determination by LC-ESI-MS mass profiling.

Chromatographic peaks 2 (m/z 430.3) and 3 (m/z 444.4), which accounted for $0.76 \%$ and $3.55 \%$ of the total RP-HPLC chromatogram area (Additional file 1) contained, respectively, the tripeptides ZNW (pyroGlu-Asn-Trp) and ZBW (pyroGluLys/Gln-Trp), characterized as weak endogenous inhibitors $\left(\mathrm{IC}_{50}\right.$ in the range of $0.15-0.95 \mathrm{mM}$ ) of the fibrinogenolytic activity of multiple snake venom $\mathrm{Zn}^{2+}$-metalloproteinases (SVMP) [49]. These peptide inhibitors regulate the proteolytic activities of SVMPs in a reversible manner under physiological conditions [50]. It is thus conceivable that they may protect glandular tissues and venom factors from the proteolytic activity of SVMPs stored at high concentration in an inactive but competent state for many months in the lumen of the venom gland of many Viperidae snakes [49, 51-53].

A number of chromatographic peaks showed fairly well isolated proteins of intact isotope-averaged molecular masses $\left(\mathrm{M}_{\text {ave }}\right)$ in the range expected for phospholipase $\mathrm{A}_{2}\left(\mathrm{PLA}_{2}\right)$ molecules, $13,948,1 \mathrm{Da}, 13,888.7 \mathrm{Da}$ and $13,850.3 \mathrm{Da}$ [Fr. 9-10, $0.85 \%$ by weight of the total venom components (TVC), Additional file 1]; 13,833.6 Da (Fr 11, 8.6\% TVC); 13,872.5 Da (Fr 12, 7\% TVC); 13,935.6 Da (Fr 13, 2.3\% TVC); 13,929.7 Da (Fr 14, 0.7\% TVC); 13,732.1 Da (Fr 15, 1.5\% TVC); 13,914.8 Da (Fr. 24-25, 2\% TVC); $13,855.9 \mathrm{Da}$ (Fr 27, 5.4\% TVC); and 13,786.9 Da (Fr 28, 4.5\% TVC) (Fig. 1, Additional file 2).

In addition, RP-HPLC fractions 18, 21, 22 and 26, all dominated by proteins migrating by SDS-PAGE at apparent molecular weights of 36,000, yielded ESI-MS masses [in Da] of 27,623.1, $27,455.2$ and $13,930.5 ; 27,636.5$ and $13,803.2$; and 30,360.4, $29,663.4$ and $13,781.9$, respectively. These molecular masses may correspond to the minor ( $<0.1 \%$ TVC) PLA $_{2}$ molecules that co-eluted with the major SVSPs in the RP-HPLC separation 

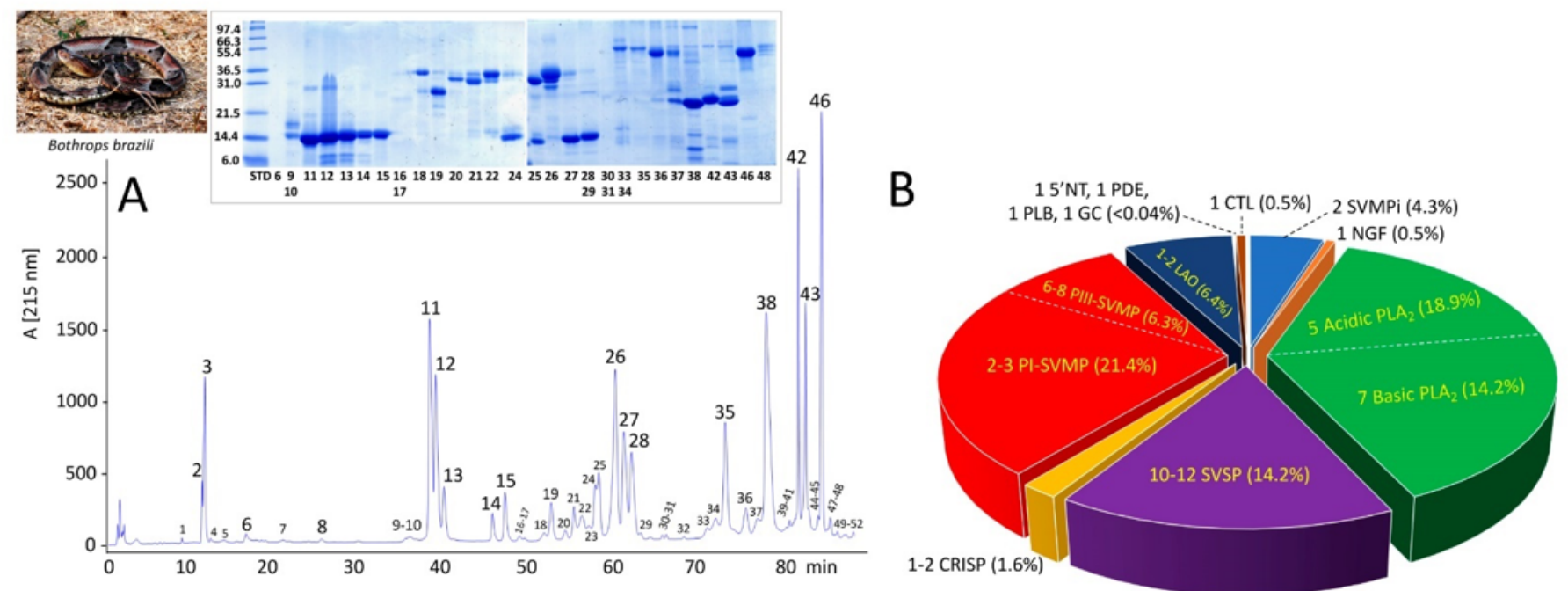

Figure 1. Venomics analysis of Bothrops brazili. (A) Reverse-phase chromatographic separation of the venom proteins of Bothrops brazili from Pará, Brazil. For venomics analysis the chromatographic fractions were collected manually and analyzed by SDS-PAGE (inset) under reduced conditions. Protein bands were excised, in-gel digested with trypsin, the resulting proteolytic peptides fragmented through LC-nESI-MS/MS, and the parent proteins identified by database searching and de novo sequencing followed by BLAST analysis (Additional file 1). The photograph of Bothrops brazili was kindly provided by Tiago Santana. (B) Pie chart displaying the estimated number and their relative occurrence (in percentage of total venom proteins) of toxins from the different protein families found in the venom proteome of Bothrops brazili (panel A). SVMPi: tripeptide inhibitors of snake venom metalloproteinase (SVMP); NGF: nerve growth factor; PLA: phospholipase $A_{2}$; SVSP: snake venom serine protease; CRISP: cysteine-rich secretory protein; PI- and PIII-SVMP: SVMPs of class PI and PIII, respectively; LAO: L-amino acid oxidase; 5'NT: 5'-nucleotidase; PDE: phosphodiesterase; PLB: phospholipase B; CTL: C-type lectin-like.

(Fig. 1, inserted SDS-PAGE analysis). It is worth noting that none of the measured molecular masses match previously reported values recorded for conspecific PLA molecules, e.g., brazilitoxin-II (PDB 4K09) (pI 9.0, $\mathrm{M}_{\text {ave }}$ : 13,741.1 Da); MTxII (4K06) (pI 9.0, 13,713.1 Da) [25]; MTx-II (4DCF) (pI 8.9, $13836.0 \mathrm{Da}$ ) [54]; Braziliase-I (pI 5.2, $\mathrm{M}_{\text {ave }}$ : 13,894.4); BraziliaseII (pI 5.3, 13,869.6) [26]. These proteins were purified from the venom of $B$. brazili of undisclosed geographic origin provided by Serpentário Sanmaru Ltda, Taquaral, São Paulo, Brazil [54] or Serpentário Proteínas Bioativas Ltda, Batatais, São Paulo, Brazil [26], strongly suggesting the occurrence of populationspecific $\mathrm{PLA}_{2}$ molecules among $B$. brazili venoms. Intraspecific compositional variation between venoms among specimens inhabiting different geographic regions has long been appreciated by herpetologists and toxinologists as a general feature of highly adaptable and widely distributed snake species, such as B. atrox $[47,48]$, and may be due to evolutionary environmental pressure acting on isolated populations.

Venom proteins eluting in reverse-phase chromatographic fractions $18\left(\mathrm{M}_{\text {ave }}: 29,899.2 \mathrm{Da}, 30,130.2 \mathrm{Da}\right.$ and 30,421.9 Da), 19 $\left(\mathrm{M}_{\mathrm{ave}}: 24,850.5 \mathrm{Da}\right), 20\left(\mathrm{M}_{\mathrm{ave}}: 28,318.0 \mathrm{Da}\right), 38\left(\mathrm{M}_{\mathrm{ave}}: 23,090.5 \mathrm{Da}\right)$ and $42 / 43\left(\mathrm{M}_{\text {ave }}: 23,317,0 \mathrm{Da}\right)$ (Fig. 1) were tentatively assigned to a cysteine-rich secretory protein (CRISP) (Fr. 19), SVSPs (Fr. 18 and 20), and PI-SVMPs (Fr. 38, 42 and 43).

As a whole, the above data suggested that the Brazil's lancehead venom comprised nine minor ( $<2.5 \%$ of total venom proteome) and five major $(>4.4 \%) \mathrm{PLA}_{2} \mathrm{~s}$, which together account for approximately $30 \%(\mathrm{w} / \mathrm{w})$ of its proteome, one minor $(1.6 \%)$ CRISP molecule, one major (Fr. 26, 8.7\%) and at least ten minor (<2.3\%) SVSPs, and 2-3 abundant (5.5-5.7\%, Fr. 42 and 43) and a major (> 13\%, Fr. 38) PI-SVMPs. In addition, SDS-PAGE analysis displayed in Figure 1 also indicated the presence in the venom of a number of protein bands compatible with minor $(<1.8 \%$, Fr. 33, 34, 36 and 37) and major (5.9\%, Fr. 35 and 10.3\%, Fr. 46) LAO and/or PIII-SVMP molecules.

\section{Bottom-up proteomic analysis of the toxin arsenal of Bothrops brazili venom from the Brazilian State of Pará}

Venom of the Brazil's lancehead (Pará) was fractionated by RP-HPLC/SDS-PAGE (Fig. 1A) and 2-DE (Fig. 2). The 1D and $2 \mathrm{D}$ electrophoretically-resolved protein bands were submitted to in-gel trypsin digestion and bottom-up peptide-centric MS/ MS analysis, followed by database matching through the online MASCOT search engine or BLAST analysis of de novo gathered peptide ion sequences (Additional files 1 and 2).

Figure $1 \mathrm{~B}$ displays the relative abundances (in percentage of the total venom proteins) of the peptide and protein classes identified. The venom proteome of $B$. brazili (Pará), comprised by at least 40-47 components (Fig. 1B), is composed predominantly by two major and three minor acidic (19\%) and two major and five minor basic (14\%) PLA molecules, 7-11 SVMP of classes PI (2-3, 21\%) and PIII (5-8, 6\%), 10-12 SVSPs (14\%) and 1-2 LAOs (6\%). Other toxin classes are: two CRISPs, one C-type lectinlike (CTL), one nerve growth factor (NGF), one 5'-nucleotidase (5'NT), one phosphodiesterase (PDE), one phospholipase B (PLB), and one glutaminyl cyclase (GC) represent together less than $2.7 \%$ of the venom proteome (Fig. 1B). This toxic arsenal may account for the potent median lethal dose $\left(\mathrm{LD}_{50}\right)$ and hemorrhagic, dermonecrotic and defibrinogenating effects reported for Peruvian B. brazili venom in the murine model [11]. 

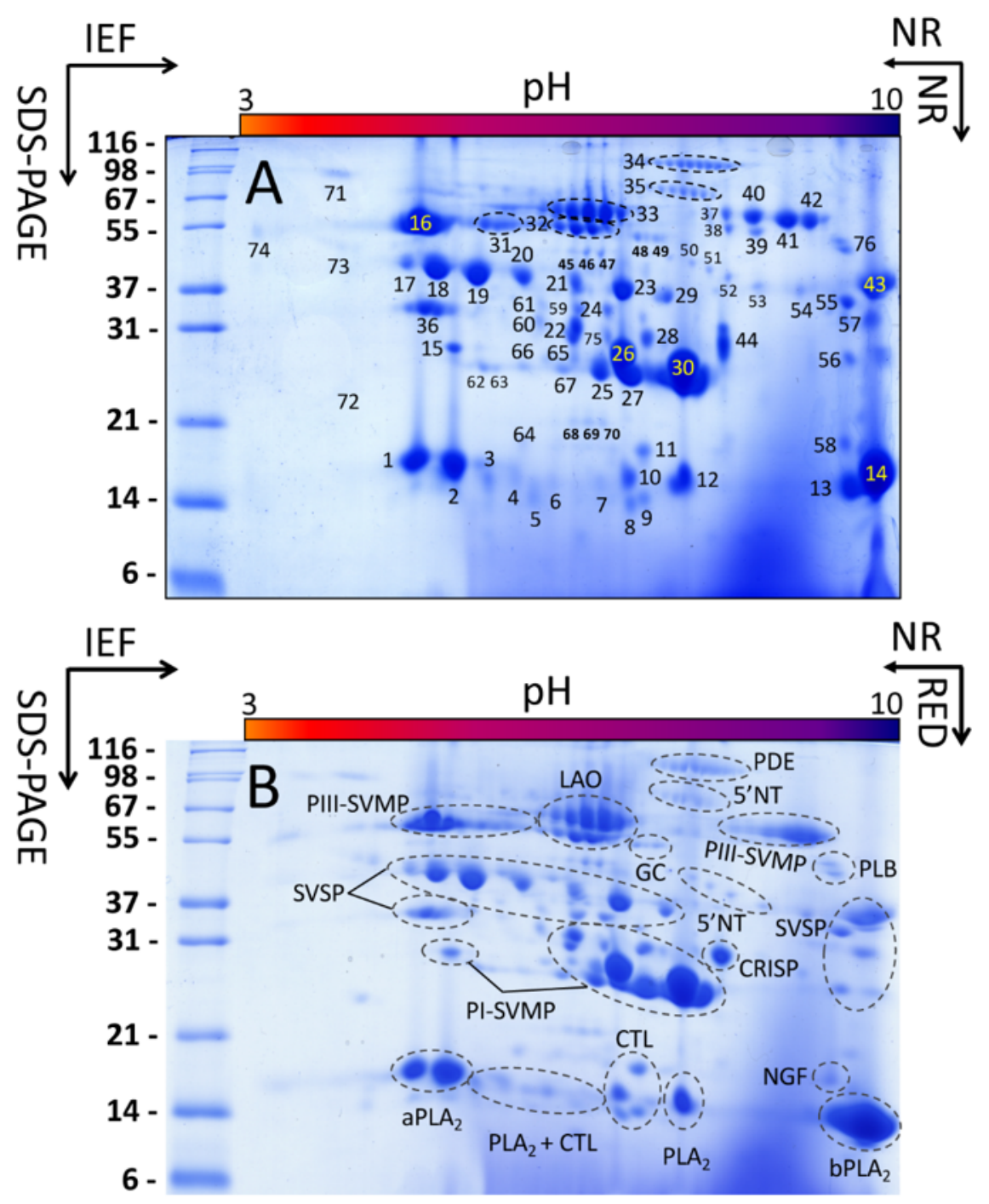

Figure 2. Two-dimensional gel electrophoresis of the Brazil's lancehead venom proteome. Two-dimensional electrophoretic separations (IEF/SDS-PAGE) of the venom proteins of Bothrops brazili from Pará. For the first (IEF) dimension, the venom proteins were focused to their isoelectric points under non-reducing (NR) conditions. For the second (SDS-PAGE) dimension, the IPGs were equilibrated at room temperature in equilibration buffer (A) without (NR) or (B) with (RED) $40 \mathrm{mM}$ of the disulfide bond reducing agent, DTT. (A) Spots submitted to in-gel trypsin digestion and bottom-up peptide-centric MS/MS analysis are numbered, whereas identified proteins are listed in Additional file 2. (B) An overview of the distribution of, and occurrence of proteoforms within, the different toxin classes identified in the venom of the Brazil's lancehead.

However, due to the absence of proteomic studies for that venom, any conclusion should be taken with due caution.

MS/MS analysis confirmed the lack of identity of the PLA molecules of $B$. brazili (Pará) with conspecific PLA sequences $_{2}$ reported in the literature. PLA molecules eluted in RP-HPLC peaks 11-14 were identified as homologs of basic BrTx-II [4K09] and MTx-II [I6L8L6, 4K06, 4DCF] [25, 54], and the tryptic peptide sequences derived from PLA 2 in RP-HPLC peak 15, 24, 25,27 and 28 showed high similarity with homologue internal sequences of acidic PLA 2 s Braziliase-I and Braziliase-II [26]. Clearly, the extent of geographic venom variability of $B$. brazili across its wide distribution range requires detailed future studies.

\section{Two-dimensional electrophoretic visualization of the Brazil's lancehead venom proteome}

Two-dimensional electrophoretic (2-DE) analysis provides a rapid way to visualize the overall venom protein complexity of a snake's venom in a single image. 2-DE and RP-HPLC/SDS-PAGE are complementary approaches that combined provide a more comprehensive view of a venom proteome than each approach separately. In addition, each of these approaches serves, by itself, a specific purpose. Thus, the presence and subunit composition of covalent complexes in a venom proteome can be conveniently addressed by comparing the 2-DE protein maps resolved under 
non-reducing (NRed) conditions in both directions (IEF and SDS-PAGE) versus non-reducing/reducing (Red) conditions [38].

Figure 2 compares the 2-DE profiles resolved in the second dimension under (A) non-reducing and (B) reducing conditions. The apparent lack of differences between both 2-DE gels clearly indicated the absence of covalently bound protein complexes. On the other hand, ESI-MS/MS sequencing of 2-DE-resolved spots labeled in Figure 2 (Additional file 2) showed the occurrence of multiple proteoforms in the range of apparent molecular weights $>55,000$ exhibiting roughly the same apparent molecular mass but differing in their pI, strongly suggesting the existence of glycoforms of PIII-SVMPs (spots 31, 37-39), LAO (spots 32, 33), PDE (spot 34) and 5'-nucleotidase (spot 35) with different content of terminal sialic acid in their oligosaccharide chains.

The molecular mass range $23-42 \mathrm{kDa}$ is populated with a complex pattern of SVSP, PI-SVMP, and CRISP molecules across the $\mathrm{pH}$ range 5-10 (Fig. 2, Additional file 2). On the other hand, and in agreement with the results of mass profiling, the 13.5-16 $\mathrm{kDa}$ range comprised mainly the $\mathrm{PLA}_{2}$ subproteome, which is made of two major acidic (pI 4.9-5.2, spots 1 and 2), two strongly basic (pI 9.5-9.8) (spots 13 and 14), and one mildly basic (pI 7.8)

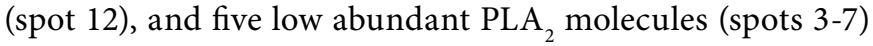
within the $\mathrm{pI}$ range 5.3-7.3. The latter spots also yielded CTL peptide ions, and molecules belonging to this toxin family were identified in spots 6, 9-11 (Fig. 2, Additional file 2). 2-DE venom decomplexation confirmed the assignments listed in the Additional file 1 and additionally showed the presence in the venom proteome of a very minor glutaminyl cyclase (GC) (spots 48-49, Fig. 2A and Additional file 2).

\section{Antivenomics assessment of the paraspecific immunorecognition towards $B$. brazili and $B$. jararaca toxins by the pentabothropic antivenom of Butantan Institute}

In Brazil, envenomings by bothropic species are clinically treated with equine polyspecific pentabothropic (SAB) or antibothropiclachetic $\mathrm{F}\left(\mathrm{ab}^{\prime}\right)_{2}$ antivenoms. Queiroz et al. [55] have reported in vitro qualitative (Western blot) and semi-quantitative (ELISA) evidence that these antivenoms exhibited variable paraspecific immunoreactivity towards nineteen venoms of bothropic snakes, including B. brazili in addition to B. alternatus, B. atrox, $B$. bilineatus, $B$. castelnaudi, B. cotiara, B. erythromelas, $B$. fonsecai, $B$. hyoprorus, B. insularis, B. itapetiningae, B. jararaca, $B$. jararacussu, B. leucurus, B. marajoensis, B. moojeni, B. neuwiedi, B. pirajai, and B. pradoi.

Here, we have applied third-generation antivenomics $[40,41]$ to compare the qualitative and quantitative immunorecognition capability of the $S A B$ antivenom produced at Butantan Institute (SP, Brazil) toward the venom toxins of B. brazili (Pará) and $B$. jararaca (reference venom). Analysis of the concentrationdependent immunocapturing profile of the $\mathrm{SAB}$ antivenom affinity columns showed paraspecific immunoreactivity against all the toxin classes of B. brazili venom (Fig. 3A, Table 1). The maximal binding capacity of immobilized (9 mg) SAB F(ab') antibodies was $1,194.2 \mu \mathrm{g}$ of $B$. brazili venom proteins, which correspond to $132.2 \mathrm{mg}$ venom/g antivenom, or $38.6 \mathrm{mg}$ of total venom proteins per vial. For a calculated average molecular mass of $35.6 \mathrm{kDa} / \mathrm{venom}$ toxin molecule, and assuming that at maximal binding both $\mathrm{F}\left(\mathrm{ab}^{\prime}\right)_{2}$ antigen-recognition sites were occupied, the antivenomics results suggest that $19 \%$ of the $\mathrm{SAB}$ antibodies recognized toxins from $B$. brazili venom. This figure fall within the range of percentages (6-28\%) of antitoxin antibodies determined for a number of commercial antivenoms [45; JJC, unpublished results].

For comparison, analysis of the concentration-dependent antivenomics profile of the $S A B$ antivenom against the reference venom of $B$. jararaca (SE) (Fig. 3B, Table 2) showed maximal binding capacity of $1,558 \mu \mathrm{g}$ per $9 \mathrm{mg} \mathrm{F}\left(\mathrm{ab}^{\prime}\right)_{2}$ affinity column, which corresponded to $173.1 \mathrm{mg}$ venom/g antivenom, or 50.6 $\mathrm{mg}$ of total B. jararaca (SE) venom proteins per vial. Assuming full occupancy of the two $\mathrm{F}\left(\mathrm{ab}^{\prime}\right)_{2}$ antigen-recognition sites, the antivenomics results indicate that $23.7 \%$ of SAB F(ab') are toxin-binding antibodies. Moreover, the neutralization potency of the $\mathrm{SAB}$ antivenom specified by Butantan Institute, $50 \mathrm{mg}$ of Bothrops jararaca reference venom/vial $(10 \mathrm{~mL})$, mirrors its maximal binding capacity, indicating that virtually all $(50 / 50.6=98.8 \%)$ toxin-binding $\mathrm{F}\left(\mathrm{ab}^{\prime}\right)_{2}$ antibodies may contribute to the capability of the SAB antivenom to neutralize the lethality of the homologous venom. On the other hand, the paraspecificity of SAB toward toxins of the heterologous B. brazili venom is due to the remarkable conservation of antigenic determinants already present in the venom of the last common ancestor of the "jararaca" and "jararacussu" clades, an event that has been dated close to the base of the radiation of genus Bothrops in the middle Miocene 14.07 Mya (CI95\% 16.37-11.75 Mya) [56, 57].

\section{Interpretating the antivenomics outcome}

Translating in vitro preclinical data to an in vivo scenario is not straightforward. Thus, although the similar total binding capacity of SAB antivenom towards B. jararaca and B. brazili venoms could be interpreted as indicative for its equivalent therapeutic potential against human envenomings by either species, the devil is in the details. In this regard, it is worth noting that although the major toxin classes PLA, PIII-SVMP, PI-SVMP, and SVSP represent, respectively, $30.6 \%, 24.6 \%$, $15.5 \%$, and $13.5 \%$ of the total venom arsenal of B. brazili, the SAB antivenom's antibodies contributing to its paraspecific recognition of $B$. brazili toxins are biasedly distributed against PI-SVMP (41\%), PIII-SVMP (32\%), SVSP (9.3\%), and PLA $(8.8 \%)$. This suggests that the ability of SAB to neutralize the toxic activities of Brazil's lancehead venom associated with PIII- and PI-SVMPs, and SVSPs is equivalent to, or greater than, the $B$. jararaca reference venom. On the other hand, counteracting the toxic activities of the major B. brazili venom $\mathrm{PLA}_{2}$ molecules may require several times the amount of antivenom. 

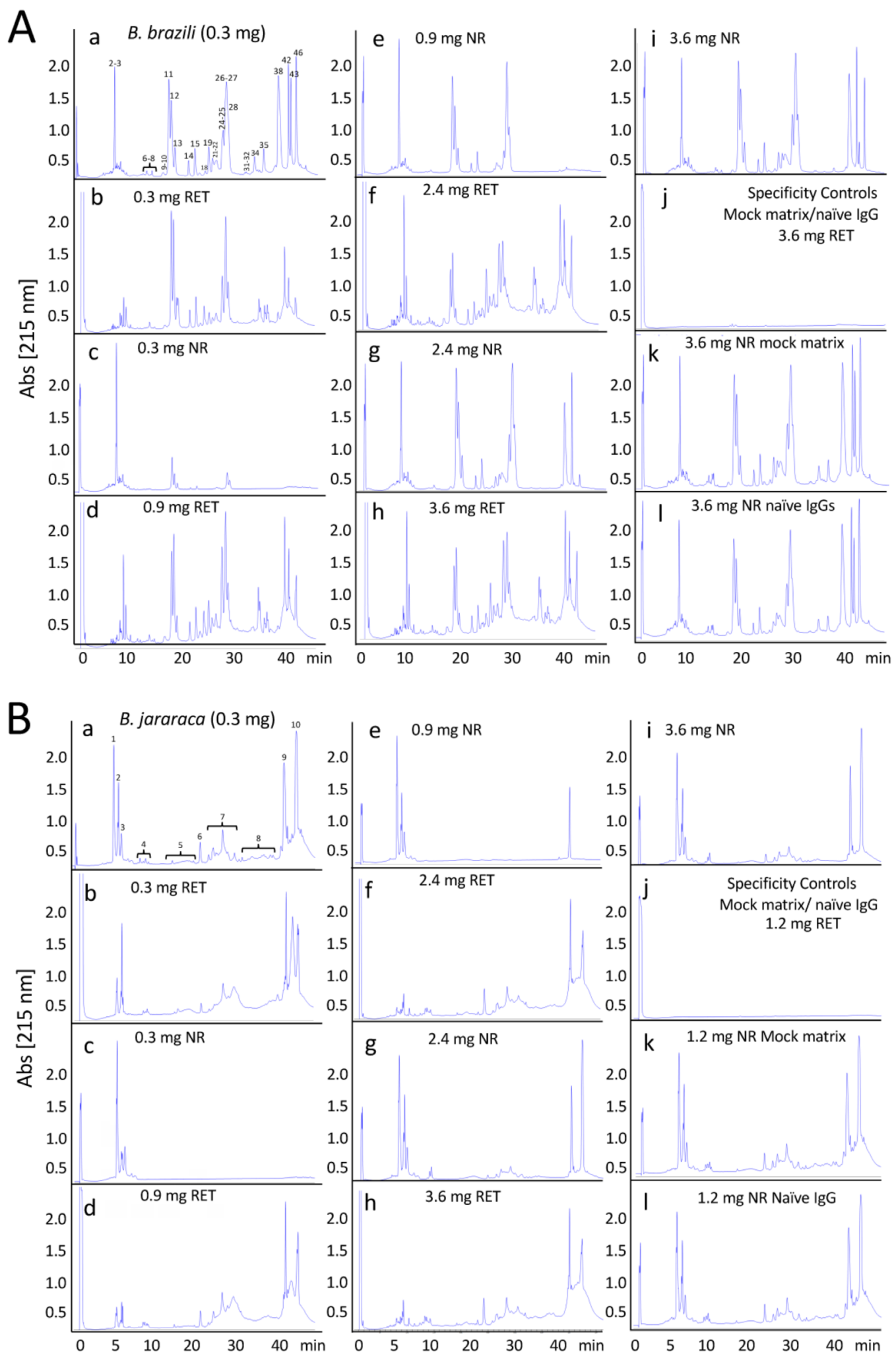

Figure 3. Comparative immunorecognition ability of the Brazilian $S A B$ antivenom towards $B$. brazili and $B$. jararaca venom toxins. (A) Third-generation antivenomic analyses of B. brazili and (B) B. jararaca venom with the pentabothropic antivenom (soro antibotrópico, SAB) produced at Butantan Institute. Reversephase chromatographic analysis of whole venom (panels $\mathbf{a}$ ) and of the non-retained and the immunoretained fractions recovered from affinity column $[9 \mu \mathrm{g}$ immobilized SAB antivenom $\left.\mathrm{F}(\mathrm{ab})^{\prime}\right)_{2}$ molecules] incubated with increasing amounts (300-3600 $\left.\mu \mathrm{g}\right)$ of venom from (A) B. brazili (Pará, Brazil) and (B) B. jararaca (SE population) are displayed in panels $\mathbf{b}$ through $\mathbf{i}$. Panels $\mathbf{j}-\mathbf{I}$ show reverse-phase HPLC separations of the retained and non-retained venom fractions on mock matrix and naïve equine $\lg \mathrm{G}$ affinity columns, respectively. 
Table 1. Concentration-dependent immunoretained (RET) Bothrops brazili (Bbr) venom proteins by SAB antivenom affinity column. Maximal binding for each RP-HPLC fraction is highlighted in bold face

\begin{tabular}{|c|c|c|c|c|c|c|c|c|c|c|}
\hline \multirow[b]{2}{*}{$\begin{array}{l}\text { RP-HPLC } \\
\text { fraction }\end{array}$} & \multicolumn{9}{|c|}{ Bothrops brazili total venom proteins $(\mu \mathrm{g})$} & \multirow[b]{2}{*}{ Toxin class } \\
\hline & & 100 & 300 & 600 & 900 & 1200 & 2400 & 3600 & Extrapolation & \\
\hline \multirow{2}{*}{ 2-3 } & $\mu g$ TOTAL & 10.09 & 30.27 & 60.55 & 90.82 & 121.09 & 242.18 & 363.28 & & \multirow{2}{*}{ SVMPi } \\
\hline & $\mu g$ RET & 0.00 & 0.00 & 0.00 & 0.00 & 0.00 & 0.00 & 0.00 & & \\
\hline \multirow{2}{*}{$6-8$} & $\mu g$ TOTAL & 1.52 & 4.56 & 9.13 & 13.69 & 18.25 & 36.50 & 54.76 & 76.00 & \multirow{2}{*}{ DC fragment } \\
\hline & $\mu g$ RET & 1.52 & 3.18 & 6.34 & 8.87 & 12.03 & 19.56 & 21.69 & 25.15 & \\
\hline \multirow{2}{*}{$9-10$} & $\mu g$ TOTAL & 0.31 & 0.93 & 1.87 & 2.80 & 3.73 & 7.46 & 11.20 & & \multirow{2}{*}{ PLA $\mathbf{A}_{2}, \mathbf{N G F}$} \\
\hline & $\mu g$ RET & 0.31 & 0.93 & 1.87 & 2.80 & 3.47 & 2.98 & 2.98 & & \\
\hline \multirow{2}{*}{11} & $\mu g$ TOTAL & 7.93 & 23.80 & 47.60 & 71.40 & 95.20 & 190.39 & 285.59 & 396.50 & \multirow{2}{*}{ PLA $_{2}$} \\
\hline & $\mu g$ RET & 7.93 & 19.22 & 21.09 & 16.71 & 20.18 & 21.43 & 22.80 & 25.85 & \\
\hline \multirow{2}{*}{12} & $\mu g$ TOTAL & 6.29 & 18.87 & 37.73 & 56.60 & 75.47 & 150.94 & 226.40 & & \multirow{2}{*}{$\mathbf{P L A}_{2}$} \\
\hline & $\mu g$ RET & 6.29 & 17.01 & 21.99 & 21.90 & 21.06 & 23.05 & 22.45 & & \\
\hline \multirow{2}{*}{13} & $\mu g$ TOTAL & 1.97 & 5.90 & 11.80 & 17.69 & 23.59 & 47.18 & 70.78 & & \multirow{2}{*}{$\mathbf{P L A}_{2}$} \\
\hline & $\mu g$ RET & 1.97 & 5.05 & 6.15 & 6.11 & 6.05 & 6.40 & 6.38 & & \\
\hline \multirow{2}{*}{14} & $\mu g$ TOTAL & 0.83 & 2.50 & 5.00 & 7.51 & 10.01 & 20.02 & 30.02 & & \multirow{2}{*}{$\mathbf{P L A}_{2}$} \\
\hline & $\mu g$ RET & 0.83 & 2.30 & 3.37 & 3.84 & 4.35 & 3.90 & 3.78 & & \\
\hline \multirow{2}{*}{15} & $\mu g$ TOTAL & 1.61 & 4.82 & 9.63 & 14.45 & 19.26 & 38.52 & 57.78 & & \multirow{2}{*}{$\mathbf{P L A}_{2}$} \\
\hline & $\mu g$ RET & 1.61 & 4.46 & 6.35 & 6.69 & 6.62 & 6.16 & 6.03 & & \\
\hline \multirow{2}{*}{ 16-17 } & $\mu g$ TOTAL & 0.21 & 0.62 & 1.24 & 1.85 & 2.47 & 4.94 & 7.42 & 10.50 & \multirow{2}{*}{ SVSP } \\
\hline & $\mu g$ RET & 0.21 & 0.62 & 1.24 & 1.85 & 2.47 & 2.94 & 3.06 & 4.16 & \\
\hline \multirow{2}{*}{18} & $\mu g$ TOTAL & 0.26 & 0.77 & 1.54 & 2.31 & 3.08 & 6.17 & 9.25 & & \multirow{2}{*}{ SVSP } \\
\hline & $\mu g$ RET & 0.26 & 0.77 & 1.54 & 2.31 & 3.08 & 2.68 & 2.34 & & \\
\hline 19 & $\mu g$ TOTAL & 1.69 & 5.08 & 10.16 & 15.24 & 20.32 & 40.63 & 60.95 & 84.50 & CRISP \\
\hline 17 & $\mu g$ RET & 1.69 & 5.08 & 10.16 & 15.24 & 20.32 & 23.73 & 25.24 & 33.56 & CRISP \\
\hline $20-22$ & $\mu g$ TOTAL & 2.61 & 7.82 & 15.64 & 23.45 & 31.27 & 62.54 & 93.82 & 130.50 & \\
\hline $20-22$ & $\mu g$ RET & 2.61 & 7.25 & 11.81 & 15.04 & 17.78 & 20.35 & 22.73 & 28.85 & SVSP \\
\hline $24-25$ & $\mu g$ TOTAL & 3.70 & 11.11 & 22.22 & 33.33 & 44.44 & 88.87 & 133.31 & & PIA SVSP \\
\hline $24-25$ & $\mu g$ RET & 3.70 & 8.48 & 19.97 & 25.14 & 25.08 & 20.47 & 18.21 & & PLA ${ }_{2}$, SVSP \\
\hline $26-28$ & $\mu g$ TOTAL & 15.63 & 46.88 & 93.77 & 140.65 & 187.54 & 375.07 & 562.61 & & \\
\hline $20-20$ & $\mu g$ RET & 15.63 & 45.42 & 45.52 & 42.40 & 41.17 & 43.65 & 41.43 & & SVSP, PLA 2 \\
\hline $30-31$ & $\mu g$ TOTAL & 0.28 & 0.83 & 1.67 & 2.50 & 3.34 & 6.67 & 10.01 & & SVSP \\
\hline $50-51$ & $\mu g$ RET & 0.28 & 0.83 & 1.67 & 2.50 & 3.34 & 3.32 & 3.31 & & SVST \\
\hline $33-34$ & $\mu g$ TOTAL & 1.83 & 5.48 & 10.96 & 16.44 & 21.92 & 43.85 & 65.77 & 91.50 & SVSP \\
\hline $35=54$ & $\mu g$ RET & 1.83 & 5.48 & 10.96 & 16.44 & 21.92 & 22.97 & 33.65 & 36.75 & SVST \\
\hline 35 & $\mu g$ TOTAL & 2.21 & 6.62 & 13.24 & 19.85 & 26.47 & 52.94 & 79.42 & 110.50 & \\
\hline & $\mu g$ RET & 2.21 & 6.62 & 13.24 & 19.85 & 26.47 & 31.65 & 34.00 & 43.24 & LAO \\
\hline 38 & $\mu g$ TOTAL & 14.60 & 43.79 & 87.59 & 131.38 & 175.18 & 350.35 & 525.53 & 730.00 & PI_SYMP \\
\hline 50 & $\mu g$ RET & 14.17 & 43.24 & 86.01 & 130.62 & 164.29 & 173.27 & 188.76 & 255.13 & PI-SVIMT \\
\hline $42-43$ & $\mu g$ TOTAL & 11.75 & 35.24 & 70.49 & 105.73 & 140.98 & 281.95 & 422.93 & 587.50 & PI-SVMP \\
\hline $42-45$ & $\mu g$ RET & 10.81 & 33.45 & 66.70 & 95.65 & 118.52 & 177.47 & 202.71 & 235.74 & riesvim \\
\hline 46 & $\mu g$ TOTAL & 14.70 & 44.10 & 88.19 & 132.29 & 176.39 & 352.78 & 529.16 & 735.00 & \\
\hline 40 & $\mu g$ RET & 13.64 & 42.81 & 85.65 & 128.28 & 163.15 & 310.34 & 318.67 & 384.76 & PIII-SVMP \\
\hline
\end{tabular}


Table 2. Concentration-dependent immunoretained (RET) Bothrops jararaca (SE) (Bj) venom proteins by SAB antivenom affinity column. Maximal binding for each RP-HPLC fraction is highlighted in bold face

\begin{tabular}{|c|c|c|c|c|c|c|c|c|c|c|}
\hline \multirow[b]{2}{*}{$\begin{array}{l}\text { RP-HPLC } \\
\text { fraction }\end{array}$} & \multicolumn{9}{|c|}{ Bothrops jararaca total venom proteins $(\mu g)$} & \multirow[b]{2}{*}{ Toxin class } \\
\hline & & 100 & 300 & 600 & 900 & 1200 & 2400 & 3600 & Extrapolation & \\
\hline \multirow{2}{*}{1} & $\mu g$ TOTAL & 8.62 & 25.86 & 51.71 & 77.57 & 103.43 & 206.86 & 310.28 & 431.00 & \multirow{2}{*}{ BPP + DISI } \\
\hline & $\mu g$ RET & 0.45 & 2.50 & 5.77 & 9.18 & 9.17 & 9.94 & 10.96 & 15.45 & \\
\hline \multirow{2}{*}{2} & $\mu g$ TOTAL & 5.03 & 15.09 & 30.19 & 45.28 & 60.37 & 120.74 & 181.12 & 250.15 & \multirow{2}{*}{ DISI } \\
\hline & $\mu g$ RET & 0.81 & 6.00 & 7.59 & 9.70 & 11.06 & 15.31 & 19.50 & 21.15 & \\
\hline \multirow{2}{*}{3} & $\mu g$ TOTAL & 2.01 & 6.04 & 12.07 & 18.11 & 24.14 & 48.29 & 72.43 & & \multirow{2}{*}{ DISI + BPP } \\
\hline & $\mu g$ RET & 0.14 & 0.20 & 0.29 & 0.38 & 0.48 & 0.51 & 0.51 & & \\
\hline \multirow{2}{*}{4} & $\mu g$ TOTAL & 0.70 & 2.11 & 4.22 & 6.34 & 8.45 & 16.90 & 25.34 & 35.00 & \multirow{2}{*}{ DC fragment } \\
\hline & $\mu g$ RET & 0.70 & 2.11 & 4.22 & 6.34 & 7.23 & 7.45 & 8.31 & 11.21 & \\
\hline \multirow{2}{*}{5} & $\mu g$ TOTAL & 2.09 & 6.26 & 12.53 & 18.79 & 25.06 & 50.11 & 75.17 & 104.50 & \multirow{2}{*}{ VEGF, PLA ${ }_{2}$} \\
\hline & $\mu g$ RET & 2.09 & 6.26 & 9.39 & 9.43 & 9.57 & 10.79 & 16.12 & 16.30 & \\
\hline \multirow{2}{*}{6} & $\mu g$ TOTAL & 1.48 & 4.44 & 8.87 & 13.31 & 17.75 & 35.50 & 53.24 & 74.00 & \multirow{2}{*}{ CRISP } \\
\hline & $\mu g$ RET & 1.48 & 4.44 & 8.87 & 12.53 & 16.78 & 30.59 & 34.08 & 40.00 & \\
\hline \multirow{2}{*}{7} & $\mu g$ TOTAL & 12.01 & 36.02 & 72.04 & 108.05 & 144.07 & 288.14 & 432.22 & 600.51 & \multirow{2}{*}{ SVSP, PLA ${ }_{2}$, CTL } \\
\hline & $\mu g$ RET & 12.01 & 36.02 & 72.04 & 105.20 & 128.17 & 143.57 & 156.93 & 206.85 & \\
\hline \multirow{2}{*}{8} & $\mu g$ TOTAL & 4.03 & 12.10 & 24.19 & 36.29 & 48.38 & 96.77 & 145.15 & 201.50 & \multirow{2}{*}{ SVSP. CTL. LAO } \\
\hline & $\mu g$ RET & 4.03 & 12.10 & 24.19 & 36.29 & 48.38 & 83.84 & 105.48 & 119.45 & \\
\hline \multirow{2}{*}{9} & $\mu g$ TOTAL & 19.20 & 57.61 & 115.22 & 172.84 & 230.45 & 460.90 & 691.34 & 960.01 & \multirow{2}{*}{ PI-SVMP } \\
\hline & $\mu g$ RET & 17.92 & 56.07 & 113.23 & 167.29 & 213.21 & 278.24 & 338.59 & 400.52 & \\
\hline \multirow{2}{*}{10} & $\mu g$ TOTAL & 44.83 & 134.48 & 268.96 & 403.43 & 537.91 & 1075.82 & 1613.74 & 2191.51 & \multirow{2}{*}{ PIII-SVMP } \\
\hline & $\mu g$ RET & 43.51 & 132.72 & 260.99 & 351.64 & 376.24 & 529.24 & 629.53 & 726.54 & \\
\hline
\end{tabular}

The average venom yield of $B$. brazili is about $270 \mathrm{mg}$ dry weight (biologist Luiz Henrique Anzaloni Pedrosa, Serpentário Proteínas Bioativas Ltda, Batatais, SP, Brazil, personal communication to AMS). For comparison, the average yield reported for B. jararaca $(25-26 \mathrm{mg}$, with a maximum of $300 \mathrm{mg}$, of dry weight [58]; 40-70 $\mathrm{mg}$ according to the snake $\mathrm{LD}_{50}$ database, http://snakedatabase.org). These figures suggest that the same therapeutic potency of SAB against both venoms. However, the treatment of a Brazil's lancehead bite injecting an average amount of venom would require a 5-13 higher SAB dose than for a similar envenoming by $B$. jararaca.

\section{Conclusion}

The Brazil's lancehead is a wide-ranging species endemic to lowlands of equatorial rainforests of northern South America. Phylogenetic analyses recovered two major lineages of $B$. brazili geographically restricted to regions north (Guiana Shield clade) and south (central and western Amazonian clade) of the Amazon River [59]. The divergence between these two $B$. brazili clades has been dated back to the Miocene-Pliocene border, $4.65 \mathrm{Mya}$, and the best-fit scenario includes colonization of the Atlantic Forest from an ancestor from the Guiana Shield region through a northern bridge during the Pleistocene about $0.36 \mathrm{Mya}$, pointing to former rain forest expansions in north-eastern South America [59].

Historical demographic analyses of $B$. brazili are consistent with the idea that the establishment of the Amazon River has favored divergence by promoting vicariant separation between lineages [59]. The origin of the modern Amazon River has been largely associated with the final uplift of the Andes, which led to the formation of the Amazon River, converting a widespread, northwest-flowing Miocene floodbasin into the current eastwardrunning Amazon Basin. The Amazon River was initiated as a transcontinental river 11.8-11.3 Mya (middle to late Miocene) and between 6.8-2.4 Mya (late Miocene to early Pleistocene) [60, 61]. The river entrenched and fully migrated onto the Amazon Fan and it was only from 2.4 Mya (late Pliocene) to the present that the Amazon fluvial system integrated regionally and acquired its current shape and size $[62,63]$. These major paleogeological changes may have had major effects on the evolutionary history of the Amazonian biota.

This work represents the first comprehensive characterization of the venom proteome of the Brazil's lancehead. The venom 
was sourced from Pará, a Brazilian state south of the Amazon River. The complementary RP-HPLC/SDS-PAGE and 2-DE protein profiles of $B$. brazili venom provide a reference map for future comparative studies of the intraspecific intra- and inter-population variations of the venom proteome of this wide geographic distributed, yet poorly studied, rainforest snake species.

The ability of SAB antivenom to recognize a broad spectrum of medically important bothropic venoms has been documented in previous works spanning the last three decades [55, 64-67]. In particular, Muniz et al. [12] reported that the Brazilian SAB antivenom neutralized the lethal activity of venoms from $B$. jararaca and $B$. brazili (obtained from a $123-\mathrm{cm}$ long female collected near the high Urucu river, Coari in the Brazilian Amazonia) with potencies of 5.5 and $1.6 \mathrm{mg}$ venom $/ \mathrm{mL}$, respectively. The antivenom showed potencies of 6.2 and $1.4 \mathrm{mg} / \mathrm{mL}$, respectively, in the neutralization of the PLA activity of $B$. jararaca and $B$. brazili venoms. The volume of $\mathrm{SAB}$ antivenom that neutralized one minimal hemorrhagic dose (MHD) [68] of B. jararaca and B. brazili venoms was $5 \mathrm{~mL}$ and $7.8 \mathrm{~mL}$, respectively. Understanding the basis of the different effectivity of SAB antivenom against homologous (B. jararaca) and heterologous (B. brazili) venoms demands the quantitative assessment of its toxin-resolved immunorecognition profile.

Herein, we have applied third-generation antivenomics to compare the specific and paraspecific immunoreactivity of the SAB antivenom against these venoms. The remarkable paraspecificity exhibited by the Brazilian SAB antivenom against the venom of $B$. brazili is mostly due to large conservation of immunoreactive epitope on hemorrhagic PI- and PIII-SVMPs across much of the natural history of Bothrops. On the contrary, SAB paraspecificity against PLA $\mathrm{s}_{2}$, which comprise the major toxin class of the Brazil's lancehead venom arsenal, is disproportionately diminished. Our antivenomics data allow the rationalization, in molecular terms, of the conclusions of the in vivo neutralization assays of Muniz et al. [12], and provide clues for designing an eventual strategy aimed at improving the spectrum of the clinical applicability of the Brazilian antibothropic polyvalent SAB antivenom.

\section{Abbreviations}

2-DE: two-dimensional gel electrophoresis; 5'NT: 5'-nucleotidase; ACN: acetonitrile; CTL: C-type lectin-like; GC: glutaminyl cyclase; IEF: isoelectric focusing; LAO: L-amino acid oxidase; $\mathrm{LD}_{50}$ : median lethal dose; MCD-F: minimum coagulant dose against fibrinogen; MCD-P: minimum coagulant dose against plasma; MDD: minimum defibrinogenating dose; MHD: minimum hemorrhagic dose; MND: minimum dermonecrotic dose; NGF: nerve growth factor; NR: non-retained; P-BAV: Peruvian bothropic antivenom; PDE: phosphodiesterase; $\mathrm{PLA}_{2}$ : phospholipase $\mathrm{A}_{2}$; PLB: phospholipases B; R: retained; SAB: soro antibotrópico (Portuguese); SDS-PAGE: SDS-polyacrylamide gel electrophoresis; SVMP: snake venom metalloproteinase; SVSP: snake venom serine proteinase; TFA: trifluoroacetic acid; TVC: total venom components.

\section{Acknowledgments}

The authors express their gratitude to the Conselho de Gestão do Patrimônio Genético (CGEN/MMA) and the Programa de Desenvolvimento Tecnológico em Ferramentas para a Saúde, PDTIS-FIOCRUZ. The photograph of Bothrops brazili shown in Figurel was kindly provided by Tiago Santana.

\section{Availability of data and materials}

The datasets generated during the current study are available in Additional file 1 (Table S1) and Additional file 2 (Table S2). Raw mass spectrometric data are available from the corresponding authors on reasonable request.

\section{Funding}

This study was partly supported by grant BFU2017-89103-P from the Ministerio de Ciencia, Innovación y Universidades, Madrid (Spain) to JJC. The authors wish to express their gratitude to Conselho Nacional de Desenvolvimento Científico e Tecnológico (CNPq/MCTIC), Coordenação de Aperfeiçoamento de Pessoal de Nível Superior (CAPES/MEC) and Fundação Rondônia de Amparo ao Desenvolvimento das Ações Científicas e Tecnológicas de Pesquisa do Estado de Rondônia (FAPERO) for financial support.

\section{Competing interests}

The authors declare that they have no competing interests.

\section{Authors' contributions}

LS, AP, JJC, CASC, performed the biochemical and proteomic characterizations. SQB carried out the antivenomics assays. LS, JJC, CASC analyzed the results. LS, AP, SQB, JJC, CASC, RDS, LAC and AMS participated in the discussion of the results, carried out a critical review of the work and assisted in drafting and structuring the manuscript. LS, JJC, CASC were responsible for the conception of the work and supervised the experimental work. All the authors read and approved the final manuscript.

\section{Ethics approval}

Not applicable.

\section{Consent for publication}

Not applicable. 


\section{Supplementary material}

The following online material is available for this article:

Additional file 1. Bottom-up MS/MS identification of peptides/proteins from adult Bothrops brazili (Pará, Brazil) venom fractionated by RP-HPLC and SDS-PAGE as displayed in Figure 1.

Additional file 2. Bottom-up MS/MS identification of protein spots from adult Bothrops brazili (Pará, Brazil) venom fractionated by 2-DE as displayed in Figure 2.

\section{References}

1. Campbell JA, Lamar WW. The venomous reptiles of the Western Hemisphere. Ithaca, Cornell University Press. ISBN-13: 978-0801441417. 2004.

2. Carrasco P, Mattoni C, Leynaud G, Scrocchi GJ. Morphology, phylogeny and taxonomy of Southamerican bothropoid pitvipers (Serpentes: Viperidae). Zool. Scripta. 2012 Feb 7;41(2):109-24.

3. Martins M, Marques OAV, Sazima I. Ecological and phylogenetic correlates of feeding habits in Neotropical pitvipers of the genus Bothrops. In Biology of the Vipers. G. Schuett, M. Höggren, ME Douglas, HW Greene editor's.). Eagle Mountain Publishing, Eagle Mountain. ISBN-13: 978-0972015400N. Pp. 307-28. 2002.

4. Carrasco PA, Venegas PJ, Chaparro JC, Scrocchi GJ. Nomenclatural instability in the venomous snakes of the Bothrops complex: Implications in toxinology and public health. Toxicon. 2016 Sep 1;119:122-8.

5. Campbell JA, Lamar WW. The venomous reptiles of Latin America. Cornell, University Press, Ithaca, NY. ISBN 10: 0801420598. 1989.

6. Warrell DA. Snakebites in Central and South America: epidemiology, clinical features, and clinical management. In the venomous reptiles of the Western Hemisphere (Campbell, J.A., Lamar, W.W., eds.), Cornell University Press, Ithaca and London. ISBN-13: 978-0801441417. pp. 709-61. 2004.

7. Gutiérrez JM. Snakebite envenomation in Central America. In Handbook of Venoms and Toxins of Reptiles. Mackessy SP editor. CRC Press, Boca Raton. ISBN: 978-0-8493-9165-1. pp. 491-507. 2009.

8. Kallel H, Mayence C, Houcke S, Mathien C, Mehdaoui H, Gutiérrez JM, et al. Severe snakebite envenomation in French Guiana: When antivenom is not available. Toxicon. 2018 May;146:87-90.

9. Smalligan R, Cole J, Brito N, Laing GD, Mertz BL, Manock S, et al. Crotaline snake bite in the Ecuadorian Amazon: randomised double blind comparative trial of three South American polyspecific antivenoms. BMJ. 2004 Nov 13;329(7475):1129.

10. Zavaleta A, Salas M. Ofidismo: envenenamiento por mordedura de serpientes. In Emergencias en Medicina Interna. Martínez-Villaverde JR, León-Barúa R, Vidal-Neira L, Losno-García R, editor's. Lima, Perú. pp. 241-60. 1996.

11. Laing GD, Yarleque A, Marcelo A, Rodriguez E, Warrell DA, Theakston RD. Preclinical testing of three South American antivenoms against the venoms of five medically-important Peruvian snake venoms. Toxicon. 2004 Jul;44(1):103-6.

12. Muniz EG, Maria WS, Estevão-Costa MI, Buhrnheim P, Chávez-Olórtegui C. Neutralizing potency of horse antibothropic Brazilian antivenom against Bothrops snake venoms from the Amazonian rain forest. Toxicon. 2000 Dec;38(12):1859-63.

13. Furtado Mde F, Cardoso ST, Soares OE, Pereira AP, Fernandes DS, Tambourgi DV, et al. Antigenic cross-reactivity and immunogenicity of Bothrops venoms from snakes of the Amazon region. Toxicon. $2010 \mathrm{Apr}$ 1;55(4):881-7.
14. Beolens B, Watkins M, Grayson M. The Eponym Dictionary of Reptiles. Baltimore: Johns Hopkins University Press. ISBN 978-1-4214-0135-5. p. 37. 2011.

15. Hoge AR. A new Bothrops from Brazil - Bothrops brazili, sp. nov. Mem Inst Butantan. 1953;25(1):15-21.

16. Werman SD. Phylogenetic relationships of Central and South American pitvipers of the genus Bothrops (sensu lato): cladistic analysis of biochemical and anatomical characters. In Biology of the Pitvipers (Campbell, J.A., Brodie, E.D., eds.), Selva, Tyler, TX. ISBN: 0-9630537-0-1. pp. 21-40. 1992.

17. Bernarde PS, Turci LCB, Machado RA. Serpentes do Alto Juruá, AcreAmazônia Brasileira. Editora da Universidade Federal do Acre-Edufac. ISBN: 978-85-8236-062-0. 166p. 2017.

18. Cunha OR, Nascimento FP. Ofidios da Amazônia VII - As serpentes peçonhentas do genero Bothrops (jararacas) e Lachesis (surucucu) da região leste do Pará (Ophidia, Viperidae). Bol Mus Paraense Emilio Goeldi. 1975;83:1-42.

19. Dixon JR, Soini P. The Reptiles of the Upper Amazon Basin, Iquitos Region, Peru. Milwaukee Public Museum, Milwaukee, 1986.

20. Zavaleta A, Campos SM. Estimación de la cantidad individual de veneno producida por serpientes venenosas peruanas. Rev Med Hered. 1992;3(Suppl 1):90.

21. Calderón LA, Sobrinho JC, Zaqueo KD, Moura AA, Grabner AN, Mazzi $M V$, et al. Antitumoral activity of snake venom proteins: new trends in cancer therapy. Biomed Res Int. 2014;2014:203639.

22. Almeida JR, Resende LM, Watanabe RK, Carregari VC, HuancahuireVega $S$, da $S$ Caldeira CA, et al. Snake venom peptides and low mass proteins: molecular tools and therapeutic agents. Curr Med Chem. 2017;24(30):3254-82.

23. Costa TR, Menaldo DL, Oliveira CZ, Santos-Filho NA, Teixeira SS, Nomizo A, et al. Myotoxic phospholipases $A_{2}$ isolated from Bothrops brazili snake venom and synthetic peptides derived from their $\mathrm{C}$-terminal region: cytotoxic effect on microorganism and tumor cells. Peptides. 2008 Oct;29(10):1645-56.

24. Huancahuire-Vega S, Ponce-Soto LA, Martins-de-Souza D, Marangoni $\mathrm{S}$, et al. Structural and functional characterization of brazilitoxins II and III (BbTX-II and -III), two myotoxins from the venom of Bothrops brazili snake. Toxicon. 2009;54(6):818-27.

25. Fernandes CA, Comparetti EJ, Borges RJ, Huancahuire-Vega S, PonceSoto LA, Marangoni S, et al. Structural bases for a complete myotoxic mechanism: crystal structures of two non-catalytic phospholipases $\mathrm{A}_{2}$-like from Bothrops brazili venom. Biochim Biophys Acta. 2013 Dec;1834:277281.

26. Sobrinho JC, Kayano AM, Simões-Silva R, Alfonso JJ, Gomez AF, Gomez $\mathrm{MCV}$, et al. Anti-platelet aggregation activity of two novel acidic Asp49phospholipases $A_{2}$ from Bothrops brazili snake venom. Int J Biol Macromol. 2018 Feb;107(Pt A):1014-22.

27. Kayano AM, Simões-Silva R, Medeiros PS, Maltarollo VG, Honorio KM, Oliveira E, et al. BbMP-1, a new metalloproteinase isolated from Bothrops brazili snake venom with in vitro antiplasmodial properties. Toxicon. 2015 Nov;106:30-41.

28. Zaqueo KD, Kayano AM, Domingos TF, Moura LA, Fuly AL, da Silva SL, et al. BbrzSP-32, the first serine protease isolated from Bothrops brazili venom: Purification and characterization. Comp Biochem Physiol A Mol Integr Physiol. 2016 May;195:15-25.

29. Bhat SK, Joshi MB, Ullah A, Masood R, Biligiri SG, Arni RK, et al. Serine proteinases from Bothrops snake venom activates PI3K/Akt mediated angiogenesis. Toxicon. 2016 Dec 15;124:63-72.

30. Delgadillo J, Palomino M, Lazo F, Rodríguez E, González E, Severino R, et al. Purificación y algunas propiedades de una hialuronidasa del veneno de la serpiente Bothrops brazili “jergón shushupe”. Rev Soc Quím Perú. 2013;79(4):348-58.

31. Gren ECK, Kitano ES, Andrade-Silva D, Iwai LK, Reis MS, Menezes MC, et al. Comparative analysis of the high molecular mass subproteomes of eight Bothrops snake venoms. Comp Biochem Physiol D Genomics Proteomics. 2019 Jun;30:113-21. 
32. Raw I, Guidolin R, Higashi HG. Antivenins in Brazil: Preparation. Handbook of Natural Toxins. Tu A editor. Marcel Dekker, New York. ISBN: 0-82478376-X. p. 557-811. 1991.

33. Brasil, Ministério da Saúde. Normas de Produção e Controle de Qualidade de Soros Antiofidicos. Diário Oficial da União. p. 23491-512. 1996.

34. Schägger H. Tricine-SDS-PAGE. Nat Protoc. 2016;1:16-22.

35. Altschul SF, Gish W, Miller W, Myers EW, Lipman DJ. Basic local alignment search tool. J Mol Biol. 1990 Oct 5;215(3):403-10.

36. Calvete JJ. Proteomic tools against the neglected pathology of snake bite envenoming. Expert Rev Proteomics. 2011 Dec;8(6):739-58.

37. Calvete JJ. Next-generation snake venomics: protein-locus resolution through venom proteome decomplexation. Exp Rev Proteomics. 2014 Mar;11(3):315-29.

38. Eichberg S, Sanz L, Calvete JJ, Pla D. Constructing comprehensive venom proteome reference maps for integrative venomics. Expert Rev Proteomics. 2015;12(5):557-73.

39. Calderón-Celis F, Cid-Barrio L, Encinar JR, Sanz-Medel A, Calvete JJ. Absolute venomics: Absolute quantification of intact venom proteins through elemental mass spectrometry. J Proteomics. 2017 Jul 5;164:33-42.

40. Pla D, Rodríguez Y, Calvete JJ. Third generation antivenomics: Pushing the limits of the in vitro preclinical assessment of antivenoms. Toxins. 2017 May;9(5):E158.

41. Calvete JJ, Rodríguez Y, Quesada-Bernat S, Pla D. Toxin-resolved antivenomics-guided assessment of the immunorecognition landscape of antivenoms. Toxicon. 2018 Jun 15;148:107-122.

42. Gonçalves-Machado L, Pla D, Sanz L, Jorge RJB, Leitão-De-Araújo M, Alves MLM, et al. Combined venomics, venom gland transcriptomics, bioactivities, and antivenomics of two Bothrops jararaca populations from geographic isolated regions within the Brazilian Atlantic rainforest. J Proteomics. 2016 Mar 1;135:73-89.

43. Howard GC, Kaser MR. Making and Using Antibodies: A Practical Handbook, Second Edition, CRC Press, Taylor \& Francis Group, Boca Raton (FL), 2nd edition,. ISBN 9781439869086. 2014.

44. Calvete JJ, Gutiérrez JM, Sanz L. Antivenomics: a proteomics tool for studying the immunoreactivity of antivenoms. In: Analyzing Biomolecular Interactions by Mass Spectrometry (1 $1^{\text {st }}$ edition) (Kool, J., Niessen, W.M., eds.), Wiley-VCH Verlag GmbH \& Co. ISBN: 978-3-527-32982-3. p. 227-39. 2015.

45. Sanz L, Quesada-Bernat S, Chen PY, Lee CD, Chiang JR, Calvete JJ. Translational Venomics: Third-Generation Antivenomics of anti-siamese Russell's viper, Daboia siamensis, antivenom manufactured in Taiwan CDC's Vaccine Center. Trop Med Infect Dis. 2018 Jun 15;3(2):E66.

46. Al-Shekhadat RI, Lopushanskaya KS, Segura À, Gutiérrez JM, Calvete JJ, Pla D. Vipera berus berus venom from Russia: venomics, bioactivities and preclinical assessment of Microgen antivenom. Toxins (Basel). 2019 Feb 1;11(2):E90.

47. Núñez V, Cid P, Sanz L, De La Torre P, Angulo Y, Lomonte B, et al. Snake venomics and antivenomics of Bothrops atrox venoms from Colombia and the Amazon regions of Brazil, Perú and Ecuador suggest the occurrence of geographic variation of venom phenotype by a trend towards paedomorphism. J Proteomics. 2009 Nov 2;73(1):57-78.

48. Calvete JJ, Sanz L, Pérez A, Borges A, Vargas AM, Lomonte B, et al. Snake population venomics and antivenomics of Bothrops atrox: Paedomorphism along its transamazonian dispersal and implications of geographic venom variability on snakebite management. J Proteomics. 2011 Apr 1;74(4):510-27.

49. Huang KF, Hung CC, Wu SH, Chiou SH. Characterization of three endogenous peptide inhibitors for multiple metalloproteinases with fibrinogenolytic activity from the venom of Taiwan habu (Trimeresurus mucrosquamatus). Biochem Biophys Res Commun. 1998 Jul 30;248(3):562-8.

50. Huang KF, Chiou SH, Ko TP, Wang AH. Determinants of the inhibition of a Taiwan habu venom metalloproteinase by its endogenous inhibitors revealed by $\mathrm{x}$-ray crystallography and synthetic inhibitor analogues. Eur J Biochem. 2002 Jun;269(12):3047-56.
51. Kato H, Iwanaga S, Suzuki T. The isolation and amino acid sequences of new pyroglutamylpeptides from snake venoms. Experientia. 1966 Jan 15;22(1):49-50.

52. Munekiyo SM, Mackessy SP. Presence of peptide inhibitors in rattlesnake venoms and their effects on endogenous metalloproteases. Toxicon. 2005 Mar 1;45(3):255-63.

53. Wagstaff SC, Favreau P, Cheneval O, Harrison RA. Molecular characterisation of endogenous snake venom metalloproteinase inhibitors. Biochem Biophys Res Commun. 2008 Feb;365(4):650-6.

54. Ullah A, Souza TA, Betzel C, Murakami MT, Arni RK. Crystallographic portrayal of different conformational states of a Lys 49 phospholipase $\mathrm{A}_{2}$ homologue: insights into structural determinants for myotoxicity and dimeric configuration. Int J Biol Macromol. 2012 Oct;51(3):209-14.

55. Queiroz GP, Pessoa LA, Portaro FC, Furtado MFD. Interspecific variation in venom composition and toxicity of Brazilian snakes from Bothrops genus. Toxicon. 2008 Nov;52(8):842-51.

56. Machado T, Silva VX, Silva MJ. Phylogenetic relationships within Bothrops neuwiedi group (Serpentes, Squamata): geographically highly-structured lineages, evidence of introgressive hybridization and Neogene/Quaternary diversification. Mol Phylogenet Evol. 2014 Feb;71:1-14.

57. Alencar LRV, Quental TB, Grazziotin FG, Alfaro ML, Martins Marcio, Venzon $M$, et al. Diversification in vipers: Phylogenetic relationships, time of divergence and shifts in speciation rates. Mol Phylogenet Evol. 2016;105:50-62.

58. Brown JH. Toxicology and Pharmacology of Venoms from Poisonous Snakes. Springfield, IL, Charles C. Thomas. ISBN 0-398-02808-7. 1973.

59. Hoorn C. An environmental reconstruction of the paleo-Amazon River system (Middle-Late Miocene, NW Amazonia). Palaeogeogr Palaeoclim Palaeoecol. 1994;112:187-238.

60. Latrubesse EM, Bocquentin J, Santos CR, Ramonell CG. Paleoenvironmental model for the late Cenozoic southwestern Amazonia: paleontology and geology. Acta Amazonica 1997 Jun;27(2):103-17.

61. Figueiredo J, Hoorn C, van der Ven P, Soares E. Late Miocene onset of the Amazon River and the Amazon deep-sea fan: Evidence from the Foz do Amazonas Basin. Geology. 2009;37(7):619-22.

62. Latrubesse EM, Cozzuol M, da Silva-Caminha SAF, Rigsby CA, Absy MA Jaramillo C. The Late Miocene paleogeography of the Amazon Basin and the evolution of the Amazon River system. Earth-Sci Rev. 2010 May;99(3-4):99-124.

63. Gutiérrez JM, Gené JA, Rojas G, Cerdas L. Neutralization of proteolytic and hemorrhagic activities of Costa Rican snake venoms by a polyvalent antivenom. Toxicon. 1985;23(6):887-93.

64. Ferreira ML, Moura-da-Silva AM, Mota I. Neutralization of different activities of venoms from nine species of Bothrops snakes by Bothrops jararaca antivenom. Toxicon. 1992 Dec;30(12):1591-602.

65. Bogarín G, Morais JF, Yamaguchi IK, Stephano MA, Marcelino JR, Nishikawa AK, et al. Neutralization of crotaline snake venoms from Central and South America by antivenoms produced in Brazil and Costa Rica. Toxicon. 2000 Oct;38(10):1429-41.

66. Segura A, Castillo MC, Núñez V, Yarlequé A, Gonçalves LR, Villalta M, et al. Preclinical assessment of the neutralizing capacity of antivenoms produced in six Latin American countries against medically-relevant Bothrops snake venoms. Toxicon. 2010 Nov;56(6):980-9.

67. Sousa LF, Nicolau CA, Peixoto PS, Bernardoni JL, Oliveira SS, Portes-Junior JÁ, et al. Comparison of phylogeny, venom composition and neutralization by antivenom in diverse species of bothrops complex. PLoS Negl Trop Dis. 2013 Sep 12;7(9):e2442.

68. Jorge RJ, Monteiro HS, Gonçalves-Machado L, Guarnieri MC, Ximenes RM, Borges-Nojosa DM, et al. Venomics and antivenomics of Bothrops erythromelas from five geographic populations within the Caatinga ecoregion of northeastern Brazil. J Proteomics. 2015 Jan 30;114:93-114. 